\section{Birlesik Dúnya Arastrma Cypriot Journal of Educational \\ Sciences}

Volume 16, Issue 2, (2021) 580-593

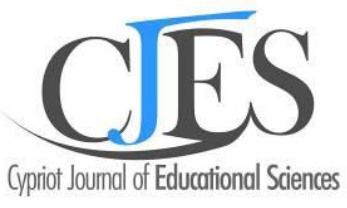

$\underline{\text { www.cjes.eu }}$

\title{
Empirical investigation into teachers' attitudes towards inclusive education: A study of future faculty of Qatari schools
}

\author{
Mohamed S. Hamid ${ }^{\text {* }}$, Department of Psychological Sciences, College of Education, Qatar University, Doha \\ 2713, Qatar, https://orcid.org/0000-0003-2349-7921
}

Nagwa Ibrahim A. Mohamed ${ }^{b}$, Department of Mental Health, College of Education, Ain Shams University, Cairo 11341, Egypt, https://orcid.org/0000-0003-4539-6849

\section{Suggested Citation:}

Hamid, M. S., \& Mohamed, N. I. A., (2021). Empirical investigation into teachers' attitudes towards inclusive education: A study of future faculty of Qatari schools. Cypriot Journal of Educational Science. 16(2), 580593. https://doi.org/10.18844/cjes.v16i2.5636

Received from December 10, 2020; revised from February 20, 2021; accepted from April 02, 2021.

${ }^{\circ} 2021$ Birlesik Dunya Yenilik Arastirma ve Yayincilik Merkezi. All rights reserved.

\begin{abstract}
Disabled students are capable of learning and growing equally to normal students, therefore the educational infrastructure of many developed countries is inclined towards an inclusive educational system. However, such students, unfortunately, are not treated well in developing countries where teachers' attitudes are a key hindrance to an inclusive education system. This study assesses future faculty attitudes towards inclusive education in Qatari independent schools. A mixed population from Arabic studies, Islamic studies, English language, social studies, mathematics, and science sections of both primary and secondary programmes are selected from the College of Education at Qatar University. The Questionnaire of Attitudes towards Inclusion (QAI) is designed for populations of all genders and sections. Data are analysed statistically initially using the t-test and, later with descriptive statistics in SPSS software. The research findings suggests that future faculty show a positive attitude concerning with inclusive education. However, this attitude toward teaching special children varies which depends on the severity of disability and the nature. Further, teachers prefer to teach mild special children for instance those with learning disabilities. Additionally, the findings reveal no substantial differences in future faculty attitudes to special children in inclusive education with respect to gender or specialization. The study emphasizes the importance of academic and psychological preparation of teachers in Qatari independent schools to understand the nature of disability and motivate them to enhance their acceptance of children with disabilities.
\end{abstract}

Keywords: Disabled students, inclusive education, Qatari independent schools, special education, teaching attitude

\footnotetext{
* AdDRESS FOR CORRESPONDENCE: Mohamed S. Hamid, Department of Psychological Sciences, College of Education, Qatar University, Doha 2713, Qatar.

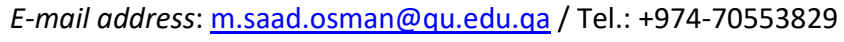




\section{Introduction}

Inclusive education is a relatively modern educational concept that has become part of the educational policies of many developed countries. The United Nations declaration of 1975 that recognizes the disabled persons' rights affirms that disabled people are capable of learning enhanced skills and can grow and integrate into the normal life of society. The declaration emphasizes the principles of social justice, equality of opportunity among all members of society and equal distribution of the prime rights which are enjoyed by normal people of all ages among normal and special children, regardless of disability or severity. Additionally, according to the declaration, special children have the right to receive suitable education and respect for their human dignity, natural growth, normal life, integration into society and freedom to live among their families and communities (Al-Qureaiti, 2005; Declaration on the Rights of Disabled Persons, 1975).

The State of Qatar plays a dominant role in special education in the region, and recognizes the prominence of disabled people on several platforms. The state is exhaustively represented by agencies and institutions concerned with disability that offer increasing attention to people with disabilities, encompassing various issues particularly those related to the quality of services offered in governmental and private centres and institutions. Qatar has issued notable resolutions and regulations for the protection of disabled persons which defend their human rights and address various abuses that happen in the workplace (Al Attiyah and Lazarus, 2012). The state is highly concerned with ensuring rights of access and maximum independence to stimulate their potential and enhance their active participation in society. Alongside prime facilities on various platforms, an interest in provision of education, equal opportunities to its citizen, especially with special needs; the Qatar shows a prominent and dominant interest in the region.

The issue of inclusive education has attracted considerable attention in educational and scientific circles. However, apart from its prominence in society, there are two diverse schools of thought, and the topic remains hotly debated. Globally, there are three major trends in educational systems regarding inclusion policy. The first school of thought strongly opposes the idea of inclusive education and supports a separate, exclusive educational infrastructure with well-equipped facilities. This trend has been successfully adopted in many countries but the results are not always satisfactory and continuous variation and improvement has become routine. The second group of experts strongly back an inclusive educational system because of its significant impact on the negative attitudes of the community and its positive impact on children with disabilities and their families (Abou Galalah, 2009; Aziz, 2005; Combs et al., 2010; Mastin, 2010). The third group perceives the issue neutrally and objectively, supporting the addition of children with mild and moderate disabilities while opposing the inclusion of children with severe or multiple disabilities (Center and Ward, 1987; Suwayti, 2016). This group is still in a transitional stage and may be considered supporters of partially inclusive education. However, given the utmost importance of an inclusive system, many educational institutions, especially in Qatar, adopt this system.

Despite the fruitful results in society of an inclusive system, there are several challenges and hindrances to its adoption. One of the most critical is the negative attitudes of faculty members to children with special needs. Some studies raise this issue (see Section 3), however, owing to increasing research demands in this area, the topic requires further detailed investigation. Faculties' negative attitudes may stem from a lack of preparation and training which limits their ability to differentiate and provide appropriate instruction to all students simultaneously. Therefore, limited preparation and training opportunities are frequently cited as significant obstacles to effective inclusive practices 
(Forlin, 2006; Gaad, 2013; Kim, 2014; Song, 2016). This shows that inducing a positive attitude among pre-service faculty or teachers before graduation from college is essential. Later, a positive attitude is reflected in the success of the inclusive classroom system.

Teachers are expected to positively deal the special children, and be responsible for and concerned about their problems alongside teaching the syllabus. They are responsible for collaboration with other personnel in the additional support section and cooperating with the family and other parties to certify the success of the inclusive education system. In the light of literature, our intention to explore this research area is centric on the assumption that the success of educational strategies is based on teachers' attitudes which significantly influence the growth of system. Another assumption is made in the form of absence of relevant study in the context of Qatari school which triggers authors to explore this work. Therefore, this research aims to identify the attitudes of future faculty (those expecting to become teachers in the near future) from the college of education at Qatar University, to inclusive education in Qatari independent schools. The study explores the impact of the variables gender (male, female), and specialization (primary, secondary) on students' attitudes to the adoption of an inclusive education system. Therefore the study aims to response the following questions:

1. What are attitudes of future teachers to inclusive education in Qatari independent schools?

2. What are future teacher's attitudes to teaching children with special needs in Qatari independent schools in the categories of intellectual disability (ID), hearing impairment (HI), autism spectrum disorder (ASD), visual impairment (VI), emotional behavioural difficulties $(E B D)$, giftedness and talent (GT), physical disability (PD), learning disability (LD), and attention deficit hyperactivity disorder (ADHD)?

3. What are the possible measures to improve the inclusive educational system?

Remaining article is organized in following sections. Section 2 covers the background of inclusive education in Qatar. Section 3 covers past studies conducted into the attitudes of teachers to inclusive education. The research method is covered in Section 4 along with the data collection and analysis methods. Section 5 covers the results and discussion, while recommendations are presented in Section 6. The conclusions and future study directions are presented in Section 7 and the research limitations and implications are presented in Section 8.

\section{Background to Inclusive Education in Qatar}

Qatar has made remarkable progress in terms of educational reform. One of the most significant developments being its adoption of the United Nations Convention for Persons with Disabilities (CRPD). It signed this convention on $30^{\text {th }}$ March 2007, and this was approved by the UN on $13^{\text {th }}$ May 2008. The CRPD contains 50 articles, and sets out legal obligations for its signatories to uphold and shelter the people's rights having disabilities, including ensuring full and equal human rights and equal opportunities to the fundamental freedoms enjoyed by others. It protects and promotes the inherent dignity respect of people with disabilities. The principle of entitlement requires the students to have right of a similar educational provision, including full participation in school activities, and the opportunity achieve their full potential. Inclusive education offers all learners meaningful and relevant learning experiences throughout their time at school.

The Qatar is dedicated to offer a wide-ranging educational services that meet the prime requirements of every student, and furnish them with excellence in quality education, and learning experience. Besides, the system actively supports and promotes the Islamic culture with Qatari traditions. The amalgamation of modern and traditional system is based on the commitment vision of adequately 
preparing students to meet the upcoming challenges and explore the opportunities and be a responsible citizen with enduring learning (SEC, 2009). With this commitment, the State of Qatar promotes special children rights in exploring suitable learning opportunities, and intermingle with each other in classrooms in a bid to shape an inclusive society (Al Attiyah and Lazarus, 2012). Therefore, in 2007, the Department of Additional Educational Support was established under the Supreme Education Council (SEC) to identify the necessities of students having disabilities. The task of this organization is to implement the integration of children into public education and provide schools with integration practices resulting from SEC policy.

SEC policy offers a guiding framework for all Qatari independent schools that defines their responsibilities to children with disabilities. They should eradicate all barriers to access to all educational experiences at all educational stages, and consider all types of special student, as illustrated in Figure 1.

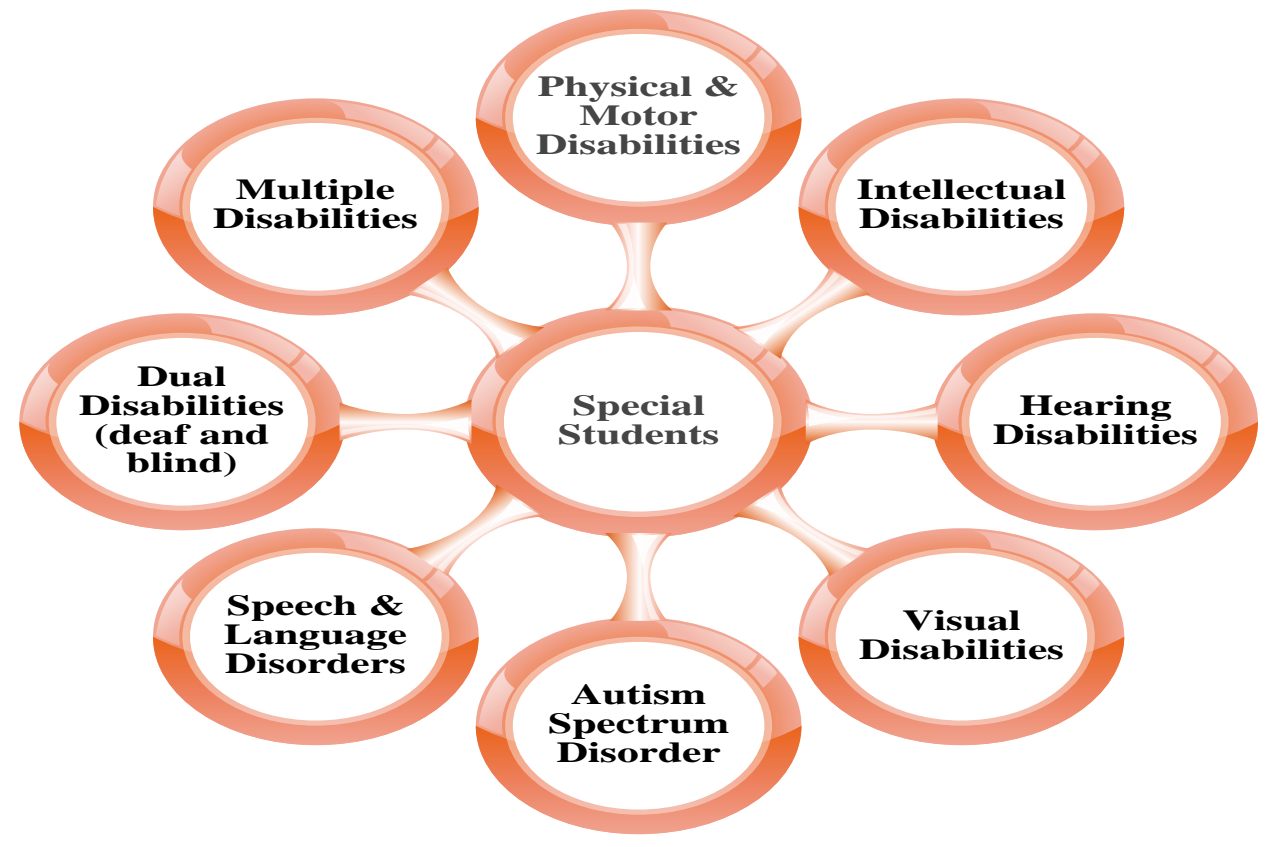

Figure 1: SEC policy consideration for special students

SEC policies promote full inclusion, reflecting procedures aimed at supporting all students in learning and participating effectively in the educational system (SEC, 2009). The vision of inclusion system encompasses on class participation of each child, and the school must play a leading role in achieving this goal. Under a full inclusion system, the classroom faculty should implement all possible educational experiences to enhance learning for all children, regardless of their needs. This involves improving teaching and assessment practices and implementing strategies that reach every children comprising with special educational requirements. The SEC has approved policies and guidelines to support schools in meeting the ethical, educational and legal requirements of education for all (SEC, 2009).

\section{Past Studies of Faculty Attitudes to Inclusive Education}

Faculty has strong and deep roots in any educational institution. Their skills, experience, educational background etc., are equally as valuable as their attitudes. However, it is hardly possible to judge their attitudes through recruitment. This area has not been given high importance for normal students, but 
attitudes cannot be overlooked in special children's education or inclusive education. Teacher's attitude towards special children largely influences the success of inclusive education. Established on this assumption, plenty of research has examined attitude of teachers in the context of the general viewpoint of inclusion system. Besides, many studies have explored the reasons that may stimulus attitudes.

A plethora of studies find that a common teacher does not hold sympathetic attitudes to inclusive education (Bataina and Al-Ruwaili, 2015; Dababneh and Al-Hassan, 2009; Kalyva et al., 2007). A few find that most teachers have positive, favourable attitudes to inclusive systems (Avramidis et al., 2000; Dupoux et al., 2005; Subban and Sharma, 2006). Meanwhile, some find neutral or uncertain attitudes among teachers to inclusive education (Padeliadu and Lampropoulou, 1997; Yuen and Westwood, 2001).

More exhaustive studies show that teachers' attitudes are dissimilar, and differ with the severity and type of disability. For example, Campbell et al. (2003) conducted a study from pre-service 274 teachers and show that typically the teachers have positive approaches with children with lesser syndromes, but their attitudes towards disability in general differ. They report that teachers feel a greater sense of ease when interacting with people with lesser or non-severe disabilities. Hastings and Oafford (2003) find teachers are more destructive about the impact of disable students on other kids, instructors and the school environment regarding emotional behavioural problems. Omar (2011) finds that $85 \%$ of teachers have negative attitudes while integrating of autistic children with normal children. Such results indicate that severity of the disability is an imperative factor in shaping attitude of teachers to inclusive education.

Several studies identify another aspect of this area of research; the correlation between the teacher's gender and their attitude to inclusive education. Most studies show that there is no significant differences of teachers' gender and their attitudes in inclusion system (Abou Galalah, 2009; AlMuhairi, 2008; Kalyva et al., 2007; Suwayti, 2016). Others find slight differences between males and females in their attitudes to inclusion. Some studies explored that the female gender teachers' attitudes comparing to male are relatively more positive (Edler et al., 2005; Fakolade et al., 2009). Inversely, some show males to have a more positive attitude than females (Bataina and Al-Ruwaili, 2015). Avramidis et al. (2000) reviewed a detailed literature on the topic of teachers' attitudes to integration. They find a positive attitude of teachers to the concept of including of children having disabilities in classroom, but less positive attitudes to the more severe forms of disability which have more complex needs to be addressed. There are more positive attitudes to physical or sensory impairments than behavioural difficulties.

The aforementioned studies show diverse results for teacher gender and attitudes toward inclusion. There is no strong evidence available that supports either side. In this regard, the present study aims to clarify gender's impact on attitudes, and intends to act as a roadmap for future precedence. The study also aims to determine the impact of teachers' specializations, primary or secondary level, an area in which there is limited research.

\section{Research Methods}

Inclusive education is a hot topic at the present time, and the attitudes of faculty is a major threat to the successful adoption of inclusive systems globally, and especially in Qatar. To achieve the stated research aim of this study, a systematic research methodology is followed (see Figure 2). Two hypotheses are set: 
1. $\mathrm{H}_{1}=$ There are significant differences in the attitudes of teachers to inclusive education in Qatari independent schools which vary according to gender (male/female).

2. $\mathrm{H}_{2}=$ There are significant differences in the attitudes of teachers to inclusive education in Qatari independent schools which vary according to the specialization or study programme (primary, secondary).

To reject the null hypothesis $\left(\mathrm{H}_{0}\right)$, a t-test is executed in SPSS software (Statistical Package for Social Sciences), with a $95 \%$ confidence level. The t-test measures differences of opinion between two groups in terms of mean values (Field, 2009). There are two types of t-test, dependent and independent. Since there are two types of participant involved (i.e. male/female, primary/secondary), an independent t-test is performed. Attitudes to inclusive education are measured with a data collection tool in SPSS, via frequency analysis. The methods are discussed, step-by-step, in the following sub-sections.

\subsection{Sample Size}

Scientifically, the sample refers to a part of the population that is suitable and accessible for collecting data, which is relatively small compared to the population. A careful selection was made of students from Qatar University for the sample. Two distinct groups of participants were approached, male and female, with primary and secondary specialization. The sample was screened by confirming each student's aim to be a future faculty member in the inclusive educational system in Qatar in the near future. Those with no ambitions to become teachers were discarded from the survey. Finally, an $\mathrm{N}=46$ sample was selected of those who agreed to respond to a self-administered survey.

The sample size is in accordance with the suggestion of Morenikeji (2006) that survey research should have at least 30 respondents. The quality of the respondents is ensured by the selection of the most suitable participants who had ambitions to serve in inclusive education schools. The 46 respondents were divided into male and female (male $\mathrm{N}=18$; female $\mathrm{N}=22$ ), from various areas of specialization (Arab studies, Islamic studies, social studies, English language, sciences, and mathematics). Another classification of the sample was made by specialization, i.e. primary and secondary education programmes. An equal number of participants were selected from each group. 


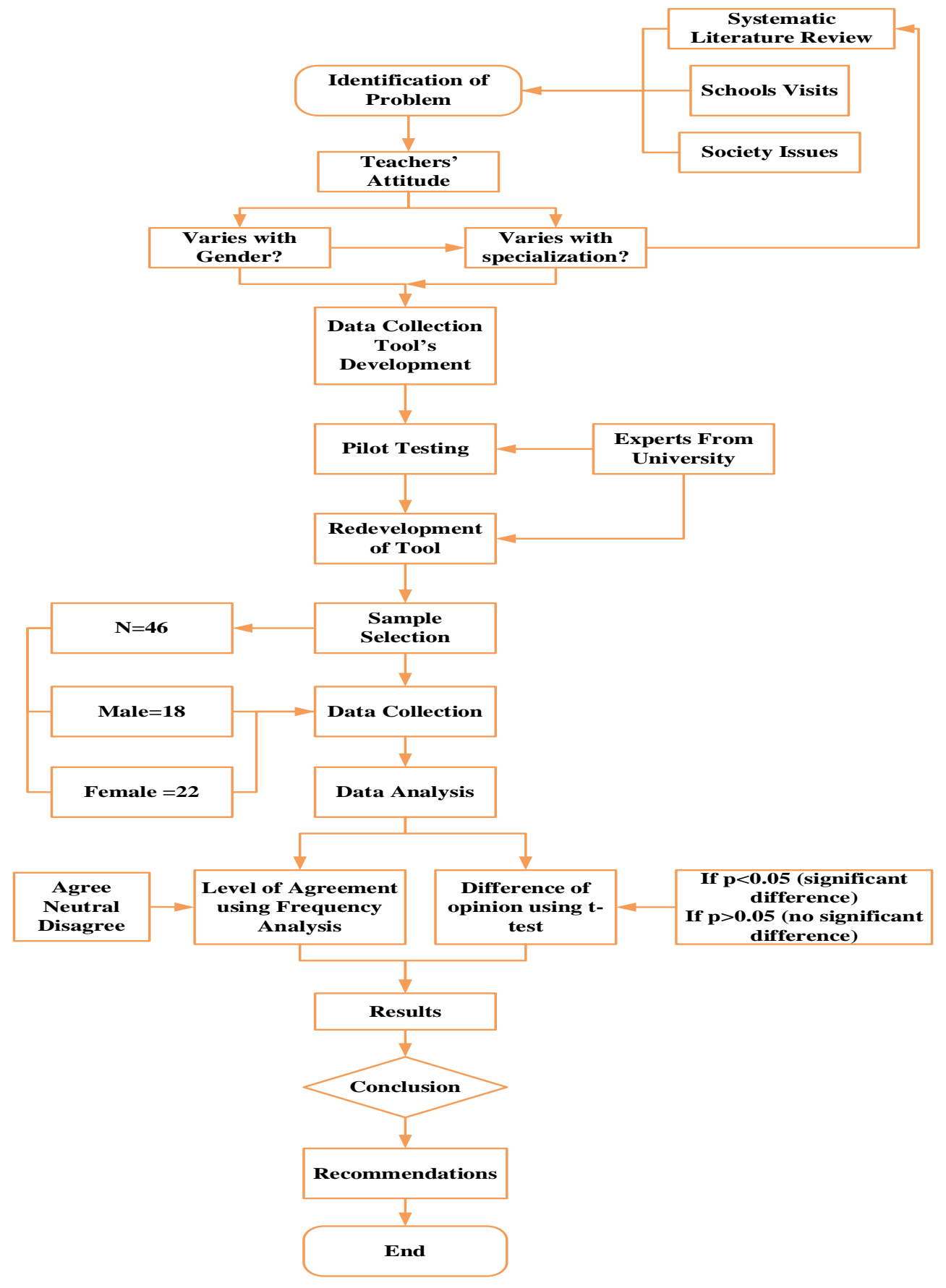

Figure 2: Systematic research methodology

\subsection{Data Collection Tool}

An exclusive survey tool has been designed for this research, called the Questionnaire of Attitudes towards Inclusion (QAI). This self-rating questionnaire consists of two parts. Part 1 has 9 items that can measure the agreement level of teachers in teaching the special children from the categories ID, ASD, $\mathrm{HI}, \mathrm{VI}, \mathrm{EBD}, \mathrm{GT}, \mathrm{PD}, \mathrm{LD}$, and ADHD. Responses are reported as Yes or No, with a Yes response indicating their agreement to teach a particular category, and a No indicating non-agreement. The responses to 
part 1 are reported by frequency analysis. Part 2 consists of 13 items measuring attitudes to inclusive education, based on a Likert scale (3=agree, $2=$ neutral, $1=$ disagree).

\subsection{Pilot Testing and Survey}

The QAI was developed by the researchers. The Qatar University Review Board, consisting of five members, reviewed the survey tool and, after certain modifications, approved it for application. It took around one and a half months to undergo the official procedures before approval. After pilot testing with the board members, the QAI was distributed to those participants who were willing to complete the questionnaire and intended to become faculty members in the near future. Participation in the QAI was based on voluntary services and kept confidential. The researchers selected the participants from primary and secondary programmes and the diverse fields listed in Section 4.1.

\subsection{Data Analysis}

The data was analysed using SPSS software, moreover, the validity and reliability of the QAI was also assessed in the software. SPSS is a powerful tool, used for similar research studies with various kinds of survey, by researchers such as Akhund et al. (2018) and Khoso et al. (2017). Descriptive statistics in the form of mean values, and standard deviations were computed along with percentages and frequencies to compute the priority of teaching for the categories of disability and special needs. A ttest for an independent sample was used to assess the differences in teachers' attitudes to inclusive education in the context of independent variables i.e. gender (male, female) and specialization (primary, secondary).

The mean score for part 2 of the QAI was calculated, and a score exceeding 28 points indicates a positive attitude. The reliability of the questionnaire was assessed in SPSS using a measure of internal consistency i.e. Cronbach's alpha value for all dimensions. The internal measure of reliability was found acceptable for both dimensions of the QAI (agreement to teaching children with special needs: 0.73; attitudes to inclusive education: 0.71). According to Phogat and Gupta (2019) and Khoso et al. (2020) any value above 0.70 is considered valid for analysis. Additionally, the correlation coefficient between the scores was calculated for the total score of the questionnaire and the score for part one, $\left(\mathrm{R}=0.52^{* *}\right)$ and part two $\left(\mathrm{R}=0.79^{* *}\right)$, where ${ }^{* *}$ means $\mathrm{p}<0.01$. This indicates that the reliability of the present study is satisfactory.

\section{Results and Discussion}

\subsection{Assessment of Teachers' Attitudes to Inclusion}

Teachers' attitudes to inclusion were calculated to ascertain the level of positive agreement. QAI data was entered into SPSS and frequency analysis and mean value analysis computed. The data obtained from the QAI is presented in Figure 3. Table 1 shows the mean score analysis of the results. The frequencies and percentages of responses shown in Figure 3 indicate that a high level of agreement on teaching LD children among most teachers (89.1\%), followed by GT (78\%) and PD (78\%). However, most student teachers showed low agreement on teaching EBD (33\%), ADHD (39\%) and ASD children (43\%). There was moderate agreement on teaching VI (57\%), HI (52\%) and ID children (52\%). 


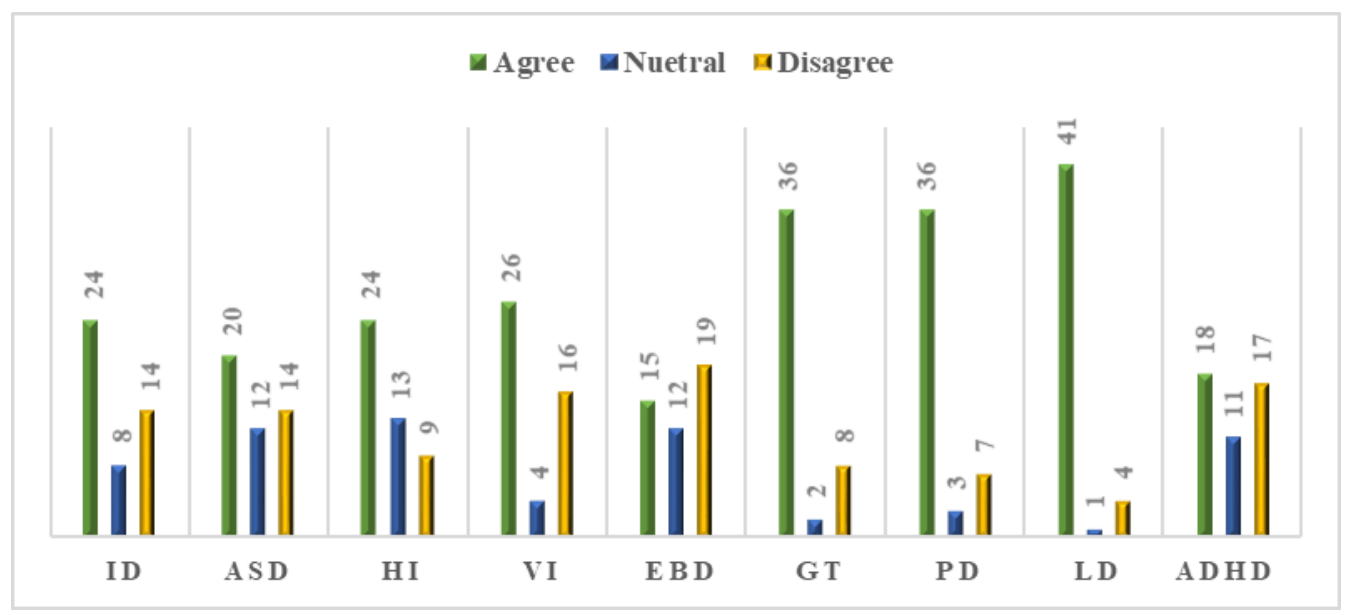

Figure 3: Teachers' attitudes to the inclusion of groups of special children

Table 1: Mean value analysis of teachers' attitudes to the inclusion of groups of special children

\begin{tabular}{lll}
\hline S. No. & Category & Mean score \\
\hline 1 & ID & 34.0 \\
2 & ASD & 32.7 \\
3 & HI & 35.7 \\
4 & VI & 34.0 \\
5 & EBD & 29.3 \\
6 & GT & 40.0 \\
7 & PD & 40.3 \\
8 & LD & 43.0 \\
9 & ADHD & 31.0 \\
\hline
\end{tabular}

According to mean value analysis shown in Table 1, no category falls below the minimum cut-off of 28.0. This indicates that future teachers in Qatar schools have a high level of agreement with an inclusive education system. However, they are reluctant to teach a few categories of disability such as EBD and ADHD, shown by their high disagreement level. These results are an indication that the administration must take active measures to treat such categories of student.

\subsection{Assessment of Teachers' Attitudes by Variable}

Two variables are used to assess the teachers' attitudes, gender and specialization. Various diverse results have been obtained in the past for these variables (see Section 3). This assessment is designed on the basis of two hypotheses outlined in the methods section. To prove the null hypothesis, as stated, an independent t-test was undertaken in SPSS. Table 2 illustrates the t-tests results of the independent groups for comparing the mean male and female attitude to inclusion.

Table 2: T-test analysis of gender differences in attitudes to inclusion

\begin{tabular}{|c|c|c|c|c|c|}
\hline Variable & & $\begin{array}{l}\text { Female } \\
(n=22)\end{array}$ & $\begin{array}{l}\text { Male } \\
(n=18)\end{array}$ & $\begin{array}{c}t- \\
\text { value }\end{array}$ & $\begin{array}{c}\text { Significance } \\
\text { level }\end{array}$ \\
\hline $\begin{array}{l}\text { Attitude to inclusive } \\
\text { education }\end{array}$ & $\begin{array}{l}M \\
S D\end{array}$ & $\begin{array}{l}29.22 \\
(3.11)\end{array}$ & $\begin{array}{l}30.33 \\
(1.03)\end{array}$ & 0.081 & Not significant \\
\hline
\end{tabular}


As shown in Table 2, two mean values (M) were computed along with the standard deviation (SD). The group means (female=29.22; male=30.33) were matched using the $t$-value. According to the $t$-value $(p=0.081 ; p>0.05)$, there is no significant difference between the agreement levels of the genders. The t-value analysis thus rejects the hypothesis that there are significant differences in teachers' attitudes to inclusive education in Qatari independent schools according to gender (male/female).

The specialization variable was assessed using a similar t-test approach. The results with respect to teacher specialization are shown in Table 3.

Table 3: T-test analysis of primary and secondary student teachers' attitudes to inclusion

\begin{tabular}{lccccc}
\hline Variable & & $\begin{array}{c}\text { Primary } \\
(\mathrm{n}=23)\end{array}$ & $\begin{array}{c}\text { Secondary } \\
(\mathrm{n}=23)\end{array}$ & $\begin{array}{c}t- \\
\text { value }\end{array}$ & $\begin{array}{c}\text { Significance } \\
\text { level }\end{array}$ \\
\hline $\begin{array}{l}\text { Attitude to inclusive } \\
\text { education }\end{array}$ & $\mathrm{M}$ & 24.30 & 22.70 & 0.277 & Not significant \\
& SD & $(14.60)$ & $(12.40)$ & & \\
\hline
\end{tabular}

As shown in Table 3, two mean values (M) were computed along with the standard deviation (SD). The group means (primary=24.30; secondary $=22.70$ ) were related using the $t$-value. According to the $t$ value $(p=0.277 ; p>0.05)$, there are no significant differences between the levels of agreement of the groups. The t-value analysis thus rejects the hypothesis that there are significant differences in teachers' attitudes to inclusive education in Qatari independent schools according to specialization or study programme (primary, secondary).

The results of the study show positive attitudes to inclusive education among future teachers. This is in accord with many previous studies, such as (Al-Muhairi, 2008; Suwayti, 2016). This positive attitude may be due to:

- Most of the students (future faculty) have spent time in primary, middle and secondary schools with colleagues with special needs.

- The students are influenced by the attitudes of the society in which they live and which takes advanced steps to care for people with special needs as part of society.

Furthermore, the study's findings show that attitude to teaching children with special needs varies according to severity and nature of the disability. Teachers prefer to deal with groups of children having mild or slight need of special attention, for instance, the giftedness or learning disabilities, but not severe disabilities such as emotional and behavioural difficulties. These results are supported by several previous studies (Avramidis et al., 2000; Center and Ward, 1987; Dababneh and Al-Hassan, 2009; MacFarlane and Woolfson, 2013; Mastin, 2010; Omar, 2011). Moreover, the findings show no significant differences in gender parameter such as males and females, or study program parameter such as primary and secondary programmes. This is consistent with the results of previous studies such as (Dababneh and Al-Hassan, 2009; Galaterou and Antoniou, 2017; Mastin, 2010; Omar, 2011; Zidane and Sadik, 2009).

\section{Recommendations}

The problem of teachers' attitudes to inclusive education is a key consideration of many school administrations and this has a negative impact on society, especially on special children and their families. Since the State of Qatar has gone beyond the normal consideration of these issues, and after 
signing agreements with the UN, it is a foremost imperative to deal with this problem. The problem of teachers' attitudes requires special and permanent kinds of solutions that work well on the ground. This study proposes that future faculty members must acquire teaching experience during their university preparation, including knowledge of inclusion and children with special needs and their problems, through study of a general course called "inclusive classrooms" and other psychological and educational courses. This is suggested by Shade and Stewart (2001). The study emphasizes the importance for all Qatar University students of awareness of the issues and characteristics of people with special needs. This could be strengthened by at least one compulsory course on special education. The study also proposes sound teacher training by institutions after recruitment. Master trainers should be hired to provide teachers with a broad understanding of learners and their needs. Also, accommodation and differentiation strategies should be central to teacher training programmes. It is imperative to note that our institutions should prepare the faculties with soft and hard skills, and strengthen them with confidence so that they could teach in inclusive settings, and bind them so firmly that they could offer suitable instruction to all children.

\section{Conclusion and Future Directions}

The State of Qatar has a great inclination towards the growth of society. Alongside the other major developments in the country, Qatar has signed a historical agreement with the UN to protect the rights of children with special needs. To strengthen this deal and groom society, the education of special children is a key agenda item for the country. The country has modern educational institutions with impressive infrastructure that serves special children within an inclusive system. However, teachers' attitudes can be a key impediment to future growth. This study assesses future faculty attitudes to inclusive education. It assesses teachers' agreement with teaching children with various disabilities in inclusive settings. Two hypotheses address the stated objectives. The data were collected exclusively from Qatari independent school students who were expecting to teach special students in the near future. The data was analysed using SPSS software in terms of various parameters centred on two variables, gender and specialization. It is concluded from the analysis that future faculty members have positive attitudes to inclusive education and are willing to teach special children with care. However, their level of agreement varies according to the severity of the children's disability. Teachers are shown to be reluctant to teach children with severe disabilities such as EBD, ADHD or ASD. The t-tests prove the null hypotheses that there is no significant difference between the groups of teachers by gender or level of specialization. Therefore, the study concludes that these factors have no impact on the teachers' attitudes. This finding is a secondary contribution to the literature, as there are various diverse findings on the impact of gender on attitudes towards special children. The research opens several avenues for further research in the form of separate research on various categories of special children. A framework is proposed to deal with the issues arising from teachers' attitudes in the form of a detailed knowledge-based system.

\section{Research Limitations and Implications}

This study covers the major aspects of teachers' attitudes, i.e. gender and specialization. During the data gathering, each participants were encouraged to understand the QAI and defined themselves accurately and honestly, but their willingness, mood, emotion, current state of mind, etc. all have impacts on the results. Furthermore, the limited sample size calls for replication using a larger quantity of participants. 
The results of this study may serve a roadmap for Ministry of Education in the State of Qatar and Qatar University to improve education and prepare teachers to serve in the inclusive educational system. This study is a strong bridge between special students and institutions.

\section{References}

Abou Galalah, S. (2009). The Attitudes towards the integration of people with special needs into educational institutions (practices and challenges). Qatar National Committee for Education, Culture and Science, 168(38). http://search.mandumah.com/Record/42435

Akhund, M. A., Khoso, A. R., Pathan, A. A., Imad, H. U., \& Siddiqui, F. (2018). Risk Attributes, Influencing the Time and Cost Overrun in Joint Venture Construction Projects of Pakistan. Engineering, Technology \& Applied Science Research, 8(4), 3260-3264. https://doi.org/10.48084/etasr.2203

Al-Muhairi, A. (2008). Attitudes of teachers towards the integration of the hearing impaired in regular schools. Journal of the Faculty of Education, University of the United Arab Emirates, 23, 181-202. http://search.shamaa.org/FullRecord?ID=33792

Al-Qureaiti, A. A. (2005). Psychology and education of people with special need (4th ed.). Cairo: Dar El fekr. https://www.anglo-egyptian.com/ar/book.php?id=27

Al Attiyah, A., \& Lazarus, B. (2012). Special education advances in the State of Qatar. In K. Mutua \& C. Sunal (Eds.), Advances in research and praxis in special education in Africa, Caribbean, and the Middle East (pp. 175-194). Charlotte, NC: Information Age Publishing. https://www.infoagepub.com/products/SpecialEducation-Research-and-Praxis-Africa-Caribbean-and-Middle-East

Avramidis, E., Bayliss, P., \& Burden, R. (2000). Student teachers' attitudes towards the inclusion of children with special educational needs in the ordinary school. Teaching and Teacher Education, 16(3), 277-293. https://doi.org/https://doi.org/10.1016/S0742-051X(99)00062-1

Aziz, S. A. (2005). Guidance for people with special needs. Dar Al Thaqafa. http://daralthaqafa.com/Item.aspx?ltemld=737

Bataina, O., \& Al-Ruwaili, M. (2015). Teachers' Attitudes towards the integration of children with motor disability in public schools in Northern Saudi Arabia. Jordanian Journal of Educational Sciences, 11(2), 145-168. http://search.shamaa.org/FullRecord?ID=110999

Campbell, J., Gilmore, L., \& Cuskelly, M. (2003). Changing student teachers' attitudes towards disability and inclusion. Journal of Intellectual \& Developmental Disability, 28(4), 369-379. https://doi.org/10.1080/13668250310001616407

Center, Y., \& Ward, J. (1987). Teachers' Attitudes Towards the Integration of Disabled Children into Regular Schools. The Exceptional Child, 34(1), 41-56. https://doi.org/10.1080/0156655870340105

Combs, S., Elliott, S., \& Whipple, K. (2010). Elementary Physical Education Teachers' Attitudes Towards The Inclusion Of Children With Special Needs: A Qualitative Investigation. International Journal of Special Education, 25. https://files.eric.ed.gov/fulltext/EJ890572.pdf

Dababneh, K., \& Al-Hassan, S. (2009). Integration of students with hearing disabilities in regular schools from the point of view of teachers. Jordanian Journal of Educational Sciences, 1(1), 14-15. https://journals.yu.edu.jo/jjes/ar/images/stories/pdf/2009/Vol5No1/jjes_vol5_no1_2009.pdf

Dupoux, E., Wolman, C., \& Estrada, E. (2005). Teachers' attitudes toward integration of students with disabilities in Haïti and the United States. International Journal of Disability, Development and Education, 52(1), 4358. https://doi.org/10.1080/10349120500071894

Edler, J., John, R., Luke, G., Leif, H., Max, R., Charles, E., Lena, T., \& Mona, P. (2005). Innovation and Public Procurement. Review of Issues at Stake. In Institue Systems and Innovation Research. http://www.proinnoeurope.eu/sites/default/files/_Innovation_and_Public_Procurement_review_of_issues_at_stake_- 
Hamid, M. S., \& Mohamed, N. I. A., (2021). Empirical investigation into teachers' attitudes towards inclusive education: A study of future faculty of Qatari schools. Cypriot Journal of Educational Science. 16(2), 580-593. https://doi.org/10.18844/cjes.v16i2.5636

_executive_summary.pdf

Fakolade, O. ., Adeniyi, S. ., \& Tella, A. (2009). Attitude of teachers towards the inclusion of special needs in general education classrooms:the case of teachers in some selected schools in Nigeria. International Electronic Journal of Elementary Education, 1(3), 157-169. https://eric.ed.gov/?id=EJ1052033

Field, A. (2009). Discovering Statistics using SPSS (Third). Sage Publications.

Forlin, C. (2006). Inclusive education in Australia ten years after Salamanca. European Journal of Psychology of Education, 21(3), 265-277. https://doi.org/10.1007/BF03173415

Gaad, E. (2013). Needs Within Higher Education In UAE: Issues And Challenges. Journal of International Education Research, 9(4), 287-292. https://doi.org/https://doi.org/10.19030/jier.v9i4.8080

Galaterou, J., \& Antoniou, A. S. (2017). Teachers' attitudes towards inclusive education: The role of job stressors and demographic parameters. International Journal of Special Education, 32(4), 643-658. https://eric.ed.gov/?id=EJ1184123

Hastings, R. P., \& Oakford, S. (2003). Student Teachers' Attitudes Towards the Inclusion of Children with Special Needs. Educational Psychology, 23(1), 87-94. https://doi.org/10.1080/01443410303223

Kalyva, E., Gojkovic, D., \& Tsakiris, V. (2007). Serbian teachers' attitudes towards inclusion. International Journal of Special Education, 22(3), 31-36. https://eric.ed.gov/?id=EJ814506

Khoso, A. R., Memon, N. A., Sohu, S., Siddiqui, F., \& Khan, J. S. (2020). Decision Criteria For Assessment Of Contractors In Prequalification Phase Of Public Projects. International Journal of Advanced Science and Technology, 29(11s), 2624-2635.

Khoso, A. R., Siddiqui, F. H., Khahro, S. H., \& Muhammad Akram, A. (2017). Entrepreneurship In Construction Industry: Motives and Barriers. International Journal of Civil Engineering and Technology (IJCIET), 8(6), 491-499.

http://www.iaeme.com/IJCIET/index.asp491http://www.iaeme.com/IJCIET/issues.asp?JType=IJCIET\&VTyp e=8\&IType=6http://www.iaeme.com/IJCIET/issues.asp?JType=IJCIET\&VType=8\&IType=6http://www.iaem e.com/IJCIET/index.asp492

Kim, Y.-W. (2014). Inclusive education in South Korea. International Journal of Inclusive Education, 18(10), 979990. https://doi.org/10.1080/13603116.2012.693402

MacFarlane, K., \& Woolfson, L. M. (2013). Teacher attitudes and behavior toward the inclusion of children with social, emotional and behavioral difficulties in mainstream schools: An application of the theory of planned behavior. Teaching and Teacher Education, 29, 46-52. https://doi.org/https://doi.org/10.1016/j.tate.2012.08.006

Mastin, D. (2010). General and Special Education Teachers' Attitudes toward Inclusion of Down Syndrome Students [Walden University]. https://eric.ed.gov/?id=ED514449

Morenikeji, W. (2006). Research and Analytical Methods for social Scientist, Planners and Environmentalist (1st ed.). Jos University press Ltd.

Omar, M. K. A. el-fetouh A. (2011). Attitudes of primary school teachers towards integrating Autism children (autonomous children) with their ordinary peers in public schools. Second Scientific Conference of the Department of Mental Health at the Faculty of Education, 415-464. https://www.researchgate.net/publication/277021342_atjahat_mlmy_almdars_alabtdayyt_nhw_dmj_atfa I_alawtyzm_alatfal_aldhatwyyn_m_aqranhm_aladyyn_fy_almdars_alamt

Padeliadu, S., \& Lampropoulou, V. (1997). Attitudes of special and regular education teachers towards school integration. European Journal of Special Needs Education, 12(3), 173-183. https://doi.org/10.1080/0885625970120301 
Phogat, S., \& Gupta, A. K. (2019). Evaluating the elements of just in time (JIT) for implementation in maintenance by exploratory and confirmatory factor analysis. International Journal of Quality and Reliability Management, 36(1), 7-24. https://doi.org/10.1108/IJQRM-12-2017-0279

SEC. (2009). Additional Educational Support Needs. A Pack of Policies, Guidance Documents And Support Materials For Schools. http://www.edu.gov.qa/Ar/SECInstitutes/EducationInstitute/CS/AdditionEducation/Pages/AdditionalEduc ation.aspx

Shade, R. A., \& Stewart, R. (2001). General Education and Special Education Preservice Teachers' Attitudes Toward Inclusion. Preventing School Failure: Alternative Education for Children and Youth, 46(1), 37-41. https://doi.org/10.1080/10459880109603342

Song, J. (2016). Inclusive Education In Japan And Korea-Japanese And Korean Teachers' Self-Efficacy And Attitudes Towards Inclusive Education. Journal of Research in Special Educational Needs, 643-. https://doi.org/10.1111/1471-3802.12324

Subban, P., \& Sharma, U. (2006). Primary school teachers' perceptions of inclusive education in Victoria, Australia. International Journal of Special Education, 21(1), 42-52. https://research.monash.edu/en/publications/primary-school-teachers-perceptions-of-inclusiveeducation-in-vic

Suwayti, A. (2016). The attitudes and opinions of teachers and administrators in public education towards the integration of non-regular children in elementary schools in the Alkhaleel Region. Journal of the College of Basic Education for Educational and Human Sciences, 25, 114-132. http://search.shamaa.org/FullRecord?ID=122556

Declaration on the Rights of Disabled Persons, (1975). https://doi.org/10.9783/9780812205381.269

Yuen, M., \& Westwood, P. (2001). Integrating students with special needs in Hong Kong secondary schools: Teachers' attitudes and their possible relationship to guidance training. International Journal of Special Education, 16(2), 69-84. https://www.researchgate.net/publication/288765069_Integrating_students_with_special_needs_in_Hon g_Kong_secondary_schools_Teachers'_attitudes_and_their_possible_relationship_to_guidance_training

Zidane, H., \& Sadik, F. (2009). The general attitudes towards inclusive education and its relation to the efficient interaction between people with special needs and their peers. Journal of Psychological Studies, 19(2), 417-429. https://search.mandumah.com/Record/84326 